\title{
Nitrogen Monoxide and Soot Oxidation in Diesel Emissions with Platinum-Tungsten/Titanium Dioxide Catalysts: Tungsten Loading Effect
}

\author{
Duck-kyu Oh ${ }^{1,2}$ (D), Young-Jae Lee ${ }^{3}$, Kwan-Young Lee ${ }^{1}$ and Jong-Soo Park ${ }^{2, *}$ \\ 1 Department of Chemical and Biological Engineering, Korea University, 145 Anam-ro, Seoul 02841, Korea; \\ ohdk@kier.re.kr (D.-k.O.); kylee@korea.ac.kr (K.-Y.L.) \\ 2 Energy Conversion \& Storage Materials Laboratory, Korea Institute of Energy Research, 152 Gajeong-ro, \\ Daejeon 34129, Korea \\ 3 Center for Environmentally Friendly Vehicle, Korea Institute of Energy Research, 152 Gajeong-ro, \\ Daejeon 34129, Korea; yjl@kier.re.kr \\ * Correspondence: deodor@kier.re.kr; Tel.: +82-42-860-3667
}

Received: 13 October 2020; Accepted: 2 November 2020; Published: 4 November 2020

\begin{abstract}
Compared with $\mathrm{Pt} / \mathrm{TiO}$, tungsten-loaded $\mathrm{Pt}-\mathrm{W} / \mathrm{TiO}_{2}$ catalysts exhibit improved activity for $\mathrm{NO}$ and soot oxidation. Using catalysts prepared by an incipient wetness method, the tungsten loading effect was investigated using Brunauer-Emmett-Teller surface areas, X-ray diffraction, transmission electron microscopy (TEM), $\mathrm{CO}$ pulse chemisorption, $\mathrm{H}_{2}$ temperature-programmed reduction, $\mathrm{NH}_{3}$ temperature-programmed desorption $\left(\mathrm{NH}_{3}-\mathrm{TPD}\right)$, and pyridine Fourier transform infrared (FT-IR) spectroscopy. Loading tungsten on the $\mathrm{Pt} / \mathrm{TiO}_{2}$ catalyst reduced the platinum particle size, as revealed in TEM images. CO pulse chemisorption showed that platinum was covered with tungsten and the dispersion of platinum decreased when $5 \mathrm{wt} . \%$ or more of tungsten was loaded. The $\mathrm{NH}_{3}$-TPD and pyridine-FT-IR results demonstrated that the number of strong acid sites and Brønsted acid sites in the catalyst were increased by the presence of tungsten. Therefore, a catalyst containing an appropriate amount of tungsten increased the dispersion of platinum, thereby increasing the number of active sites for $\mathrm{NO}$ and soot oxidation, and increased the acidity of the catalyst, thereby increasing the activity of soot oxidation by $\mathrm{NO}_{2}$.
\end{abstract}

Keywords: soot; particulate matter (PM); exhaust gas after-treatment; platinum catalyst; oxidation catalyst; $\mathrm{Pt} / \mathrm{tio}_{2}$

\section{Introduction}

Globally, harmful exhaust emissions regulations have been tightened owing to the increasing use of diesel engines in various fields, such as coal-fired power plants, ships, aviation, and automobiles [1,2]. Exhaust emissions from diesel engines include hydrocarbons, soot, NOx, SOx, and carbon monoxide. Among these emissions, soot, which consists of unburned carbon particles, can cause air pollution, various respiratory diseases, and lung cancer. The World Health Organization (WHO) and the California Air Resources Board (CARB) classify soot as a first-level carcinogen [3]. The European Union (EU) introduced the EURO emission regulation in 1994 as a means to reduce the emission of pollutants in the exhaust gas of diesel cars. EURO-6c was introduced in September 2017, which applies the Worldwide Harmonized Light Vehicle Test Procedure (WLTP) and Real Driving Emissions (RDE) instead of the New European Driving Cycle (NEDC), an existing EURO-6 emission measurement method. As a result, it has become more difficult to meet emission limits [4].

Methods for reducing soot include pre-treatment technologies, which involve fuel reforming and improvement of combustion conditions, and post-treatment technologies, which involve the collection 
and removal of soot in a diesel particulate filter (DPF) (active regeneration, combination regeneration, and passive regeneration) [5]. The mechanisms of soot oxidation can be summarized as follows.

$$
\begin{gathered}
\mathrm{C}_{- \text {soot }}+\mathrm{O}_{2} \rightarrow \mathrm{CO}_{2} \\
2 \mathrm{NO}+\mathrm{O}_{2} \rightarrow 2 \mathrm{NO}_{2} \\
\mathrm{C}_{- \text {soot }}+2 \mathrm{NO}_{2} \rightarrow \mathrm{CO}_{2}+2 \mathrm{NO}
\end{gathered}
$$

The reaction to oxidize soot using $\mathrm{O}_{2}$, as shown in Equation (1), occurs at temperatures of $550{ }^{\circ} \mathrm{C}$ or higher; therefore, post-treatment technologies based on this reaction require a separate heat source to raise the DPF temperature. In addition, when a large amount of soot is combusted, the exothermic reaction may raise the temperature of the catalyst and the DPF to approximately $1000{ }^{\circ} \mathrm{C}$, thereby causing degradation of the catalyst and structural damage to the filter. In contrast, NO, which accounts for $80-90 \%$ of NOx in diesel exhaust gas, can be oxidized using a DPF loaded with a catalyst and the generated $\mathrm{NO}_{2}$ can then oxidize soot, as shown in Equations (2) and (3). As this process occurs at a lower temperature $\left(250^{\circ} \mathrm{C}\right)$, a separate heat source is not required to increase the temperature of the DPF, and the possibility of durability degradation owing to thermal aging of the catalyst and filter is low $[6,7]$.

As platinum catalysts have high oxidation activities, many studies on soot oxidation have focused on such catalysts. Table 1 provides a summary of platinum catalysts that have been applied for soot oxidation. Oi-Uchisawa et al. [8] studied the characteristics of soot oxidation by loading $0.3 \mathrm{wt} . \%$ platinum on $\mathrm{TiO}_{2}, \mathrm{ZrO}_{2}, \mathrm{SiO}_{2}$, and $\mathrm{Al}_{2} \mathrm{O}_{3}$ supports. When the reaction gas contained $\mathrm{SO}_{2}$, the catalyst on the $\mathrm{TiO}_{2}$ support showed high activity for soot oxidation, whereas the catalysts on $\mathrm{SiO}_{2}$ and $\mathrm{Al}_{2} \mathrm{O}_{3}$ supports showed low activities. The specific surface area and the platinum dispersion did not significantly affect the catalytic activities of these catalysts. However, in sulfate accumulation experiments, accumulation of $\mathrm{SO}_{4}{ }^{2-}$ was observed on platinum in the $\mathrm{Pt} / \mathrm{SiO}_{2}$ catalyst and on $\mathrm{TiO}_{2}$ in

\begin{tabular}{|c|c|c|c|c|c|}
\hline Catalyst & Feed & GHSV $\left(h^{-1}\right)^{a}$ & Catalyst:Soot & $\mathrm{T}_{50}\left({ }^{\circ} \mathrm{C}\right)^{\mathrm{b}}$ & Ref. \\
\hline $\mathrm{Pt}[1] / \mathrm{TiO}_{2}$ & $\begin{array}{c}550 \text { ppm NO, } 1.5 \text { ppm } \mathrm{SO}_{2} \\
7.5 \% \mathrm{O}_{2}, 8 \% \mathrm{H}_{2} \mathrm{O}, \mathrm{N}_{2} \text { bal. }\end{array}$ & 96,000 & $100: 1$ & 415 & [8] \\
\hline $\mathrm{Pt}[1] / \mathrm{Al}_{2} \mathrm{O}_{3}$ & 1000 ppm NO, $3 \% \mathrm{O}_{2}$, He bal. & 30,000 & 9:1 & 550 & [9] \\
\hline $\mathrm{Pt}[1]-\mathrm{K}[5.4] / \mathrm{Al}_{2} \mathrm{O}_{3}$ & 1000 ppm NO, $3 \% \mathrm{O}_{2}$, He bal. & 30,000 & $9: 1$ & 450 & [9] \\
\hline $\mathrm{Pt}[2.5] / \mathrm{CeO}_{2}$ & 600 ppm NO, $10 \% \mathrm{O}_{2}$, Ar bal. & 70,000 & $4: 1$ & 390 & [10] \\
\hline $\operatorname{Pt}[0.5] / \mathrm{MnCeAl}$ & 1000 ppm NO, $10 \% \mathrm{O}_{2}, \mathrm{~N}_{2}$ bal. & - & $10: 1$ & 442 & [11] \\
\hline $\mathrm{Pt}[1] / \mathrm{H}-\mathrm{ZSM} 5$ & $1000 \mathrm{ppm} \mathrm{NO}, 10 \% \mathrm{O}_{2}, \mathrm{~N}_{2}$ bal. & 30,000 & $10: 1$ & 440 & [12] \\
\hline $\mathrm{Pt}[1] / \mathrm{H}-\mathrm{ZSM} 5$ & 500 ppm NO, $10 \% \mathrm{O}_{2}, \mathrm{~N}_{2}$ bal. & 30,000 & $5: 1$ & 433 & [13] \\
\hline $\mathrm{Pt}[1]-\mathrm{W}[3] / \mathrm{TiO}_{2}$ & $\begin{array}{c}300 \text { ppm NO, } 3 \text { ppm } \mathrm{SO}_{2}, 10 \% \\
\mathrm{O}_{2}, 5 \% \mathrm{H}_{2} \mathrm{O}, \mathrm{N}_{2} \text { bal. }\end{array}$ & 50,000 & $4: 1$ & 324 & $\begin{array}{l}\text { In this } \\
\text { study }\end{array}$ \\
\hline
\end{tabular}
the $\mathrm{Pt} / \mathrm{TiO}_{2}$ catalyst, indicating that the activity of platinum, which is an active metal, was maintained.

Table 1. Comparison of the activities of various platinum catalysts for soot oxidation.

${ }^{a} \mathrm{GHSV}\left(\mathrm{h}^{-1}\right)$ (gas hourly space velocity); ${ }^{\mathrm{b}} \mathrm{T}_{50}\left({ }^{\circ} \mathrm{C}\right)$ is the temperature required to achieve $50 \%$ soot combustion in the soot oxidation experiment; the lower the better.

Matarrese et al. [9] performed soot experiments using a $\mathrm{Pt}[1]-\mathrm{K}[5.4] / \mathrm{Al}_{2} \mathrm{O}_{3}$ catalyst and found that the activity of soot oxidation was increased by the NOx adsorption and desorption characteristics of potassium. Krishna et al. [10] studied soot oxidation using a $\mathrm{CeO}_{2}$ support with redox properties and an excellent oxygen storage capacity. They explained that the reactive oxygen species present on the $\mathrm{CeO}_{2}$ support of a $\mathrm{Pt}[2.5] / \mathrm{CeO}_{2}$ catalyst oxidized $\mathrm{NO}$ adsorbed on platinum, thereby activating the soot oxidation process. In addition, Liu et al. [11] added $\mathrm{MnOx}-\mathrm{CeO}_{2}$ to $\mathrm{Al}_{2} \mathrm{O}_{3}$ to enhance the thermal stability of the $\mathrm{Pt} / \mathrm{Al}_{2} \mathrm{O}_{3}$ catalyst and the activity of soot oxidation. This modification lowered $\mathrm{T}_{50}$ $\left({ }^{\circ} \mathrm{C}\right.$ ) (temperature with a $50 \%$ soot conversion rate) from 474 to $442{ }^{\circ} \mathrm{C}$ for soot oxidation. However, the active sites of catalysts containing $\mathrm{CeO}_{2}$ and alkaline metals such as potassium are poisoned during reactions involving $\mathrm{SO}_{2}$, resulting in catalyst deactivation $[10,11]$. 
Liu et al. [12] studied soot oxidation using a Pt/ZSM-5 catalyst to reduce poisoning of the catalyst by $\mathrm{SO}_{2}$. During $\mathrm{NO}$ oxidation in the presence of $\mathrm{SO}_{2}$, a higher amount of $\mathrm{NO}_{2}$ was produced at a low temperature when ZSM- 5 was used rather than $\mathrm{Al}_{2} \mathrm{O}_{3}$ as a support for platinum. During soot oxidation in the presence of $\mathrm{SO}_{2}, \mathrm{~T}_{50}\left({ }^{\circ} \mathrm{C}\right)$ decreased by $20{ }^{\circ} \mathrm{C}$ with the Pt/ZSM- 5 catalyst. However, a small amount of platinum was located in the micropores $(0.57 \mathrm{~nm})$ of ZSM-5, and it was difficult for soot larger than the pore size of ZSM-5 to come into contact with platinum in the pores. Therefore, to prevent platinum from being present in the zeolite pores, Gao et al. [13] synthesized platinum nanoparticles with an average particle size of $7.5 \mathrm{~nm}$ and then loaded the particles on an H-ZSM-5 support. Using this catalyst, $\mathrm{T}_{50}\left({ }^{\circ} \mathrm{C}\right)$ of $433^{\circ} \mathrm{C}$ was obtained, even though the amount of $\mathrm{NO}$ was reduced to $500 \mathrm{ppm}$ in the soot oxidation experiment. Tungsten is known to increase the acidity and NOx adsorption properties of catalysts [14]. However, heretofore, there has been no exploration of tungsten-added Pt catalysts for their soot oxidation activity. The exhaust gas temperature required for passive regeneration is gradually being lowered owing to the development of exhaust gas recirculation (EGR) and diesel engine combustion technology. Therefore, to oxidize soot by passive regeneration, it is necessary to develop a catalyst with excellent activity at low temperatures. In this study, we investigated the effect of the tungsten content in a $\mathrm{Pt} / \mathrm{TiO}_{2}$ catalyst on the soot oxidation characteristics at low exhaust gas temperatures. To determine the oxidation characteristics of soot on the catalyst, we confirmed the formation of $\mathrm{NO}_{2}$, which acts as an oxidant of soot, and examined soot oxidation by $\mathrm{NO}_{2}$ and $\mathrm{NO}$ reaction gases. Moreover, tungsten-loaded $\mathrm{Pt} / \mathrm{TiO}_{2}$ catalysts were characterized and, based on the results, their oxidation characteristics were investigated.

\section{Results and Discussion}

\subsection{Catalyst Characterization}

Table 2 summarizes the results of the BET (Brunauer-Emmett-Telle) analysis. When the tungsten loading amount on the catalyst increased to $3 \mathrm{wt} . \%$, the specific surface area increased by approximately $3.3 \mathrm{~m}^{2} / \mathrm{g}$ relative to that of the catalysts with $0 \mathrm{wt} . \%$ tungsten. However, when the tungsten loading amount was more than $5 \mathrm{wt} . \%$, the specific surface area decreased. The specific pore volumes were similar for all the catalysts, but the average pore diameter decreased from 28.9 to $26.6 \mathrm{~nm}$ as the tungsten content increased.

Table 2. Analysis of the structural characteristics of $\mathrm{Pt}-\mathrm{W}[\mathrm{x}] / \mathrm{TiO}_{2}$ catalysts (BET surface area $\left(\mathrm{S}_{\mathrm{BET}}\right)$, external surface area $\left(\mathrm{S}_{\mathrm{ext}}\right)$, pore volume $\left(\mathrm{V}_{\mathrm{P}}\right)$, and average pore size $\left.\left(\mathrm{D}_{\mathrm{P}}\right)\right)$.

\begin{tabular}{ccccc}
\hline Sample & $\mathbf{S}_{\text {BET }}\left(\mathbf{m}^{\mathbf{2}} / \mathbf{g}\right)$ & $\mathbf{S}_{\mathbf{e x t}}\left(\mathbf{m}^{\mathbf{2}} \mathbf{g}\right)$ & $\mathbf{V}_{\mathbf{P}}\left(\mathbf{m}^{\mathbf{2}} / \mathbf{g}\right)$ & $\mathbf{D}_{\mathbf{P}}(\mathbf{n m})$ \\
\hline W[0] & 51.5 & 48.1 & 0.37 & 28.9 \\
W[1] & 54.1 & 49.5 & 0.37 & 27.5 \\
W[3] & 54.8 & 47.7 & 0.38 & 27.5 \\
W[5] & 54.7 & 46.4 & 0.35 & 25.9 \\
W[7] & 52.8 & 46.3 & 0.35 & 26.6 \\
\hline
\end{tabular}

The XRD (X-ray diffraction) patterns of the Pt-W[x]/TiO ${ }_{2}$ catalysts are shown in Figure 1. Anatase and rutile peaks, which are characteristic of $\mathrm{TiO}_{2}$, were observed for all the synthesized catalysts, but no platinum or WOx peaks were detected. Platinum may not have been observed because the metal loading amount on the catalyst was as low as $1 \mathrm{wt} . \%$ [15]. In the case of WOx, the characteristic peaks $\left(2 \theta=23.3^{\circ}, 24.4^{\circ}\right.$, and $\left.33.8^{\circ}\right)$ were not observed even when the metal loading amount on the catalyst was $7 \mathrm{wt} . \%$. This suggests that amorphous or nano-sized WOx was well dispersed on $\mathrm{TiO}_{2}[16]$. 


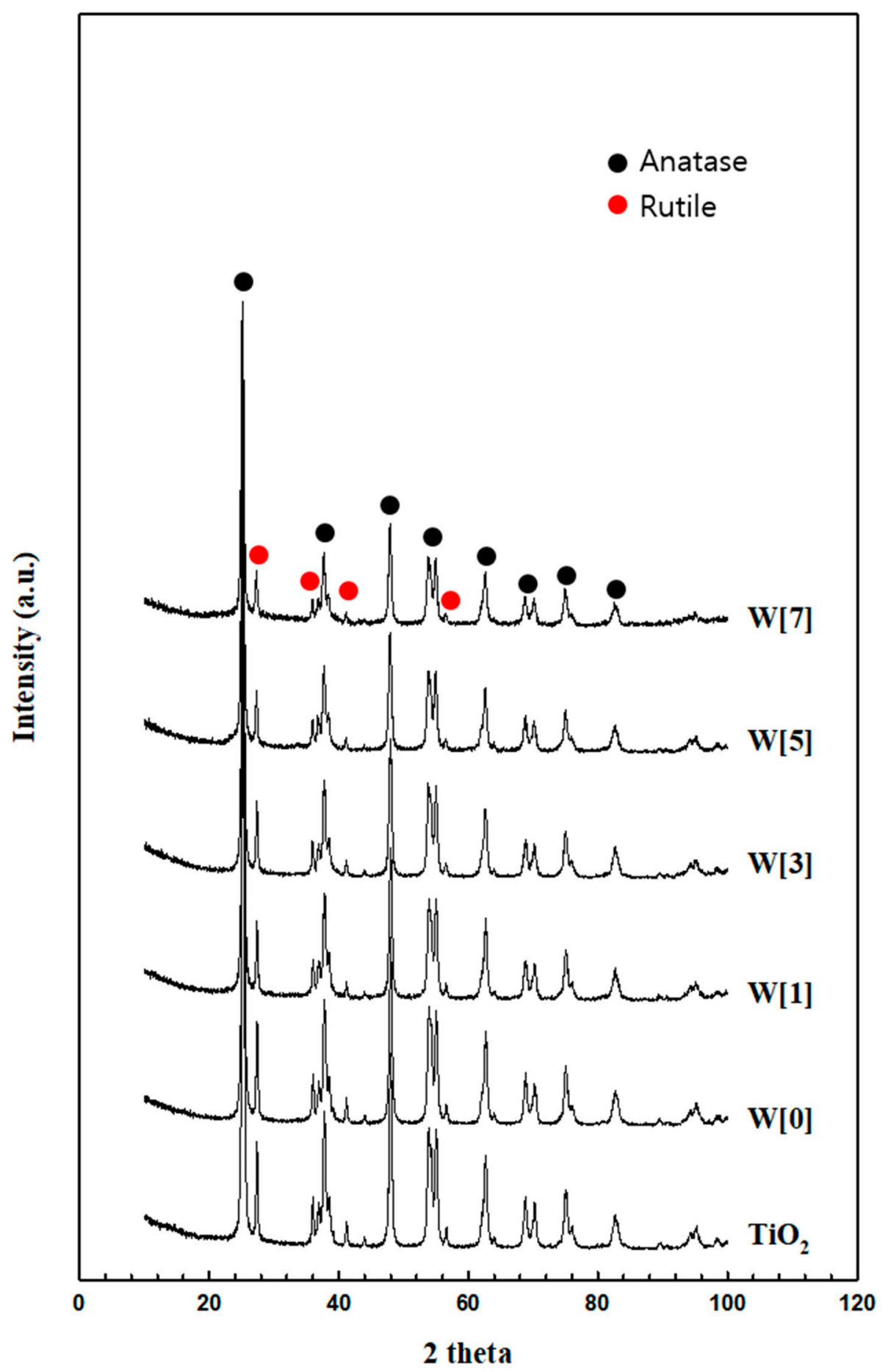

Figure 1. XRD patterns of $\mathrm{Pt}-\mathrm{W}[\mathrm{x}] / \mathrm{TiO}_{2}$ catalysts.

Figure 2 shows FE-TEM (field emission transmission electron microscopy) images, S-TEM (scanning transmission electron microscopy) images, and the platinum particle size distributions of the $\mathrm{Pt}-\mathrm{W}[\mathrm{x}] / \mathrm{TiO}_{2}$ catalysts. In the case of the $\mathrm{Pt}-\mathrm{W}[0] / \mathrm{TiO}_{2}$ catalyst (Figure $2 \mathrm{a}$ ) without tungsten, the average particle size of platinum was $2.5 \mathrm{~nm}$. In contrast, the average particle sizes of platinum in $\mathrm{Pt}-\mathrm{W}[3] / \mathrm{TiO}_{2}$ (Figure 2a) and $\mathrm{Pt}-\mathrm{W}[5] / \mathrm{TiO}_{2}$ (Figure 2c) were 1.8 and $1.6 \mathrm{~nm}$, respectively. The platinum particle size distributions show that the size of the platinum particles decreased and the width of the particle size distribution narrowed as the tungsten content of the catalyst increased. However, tungsten on the surface of $\mathrm{TiO}_{2}$ was not observed to form clusters (Figure 2b,c). EDS (energy-dispersive 
X-ray spectroscopy) mapping was performed to confirm the distribution of platinum and tungsten on the catalyst surface, and the results are shown in Figure 3. Tungsten, which was difficult to observe using S-TEM, was found to be distributed throughout the catalyst.
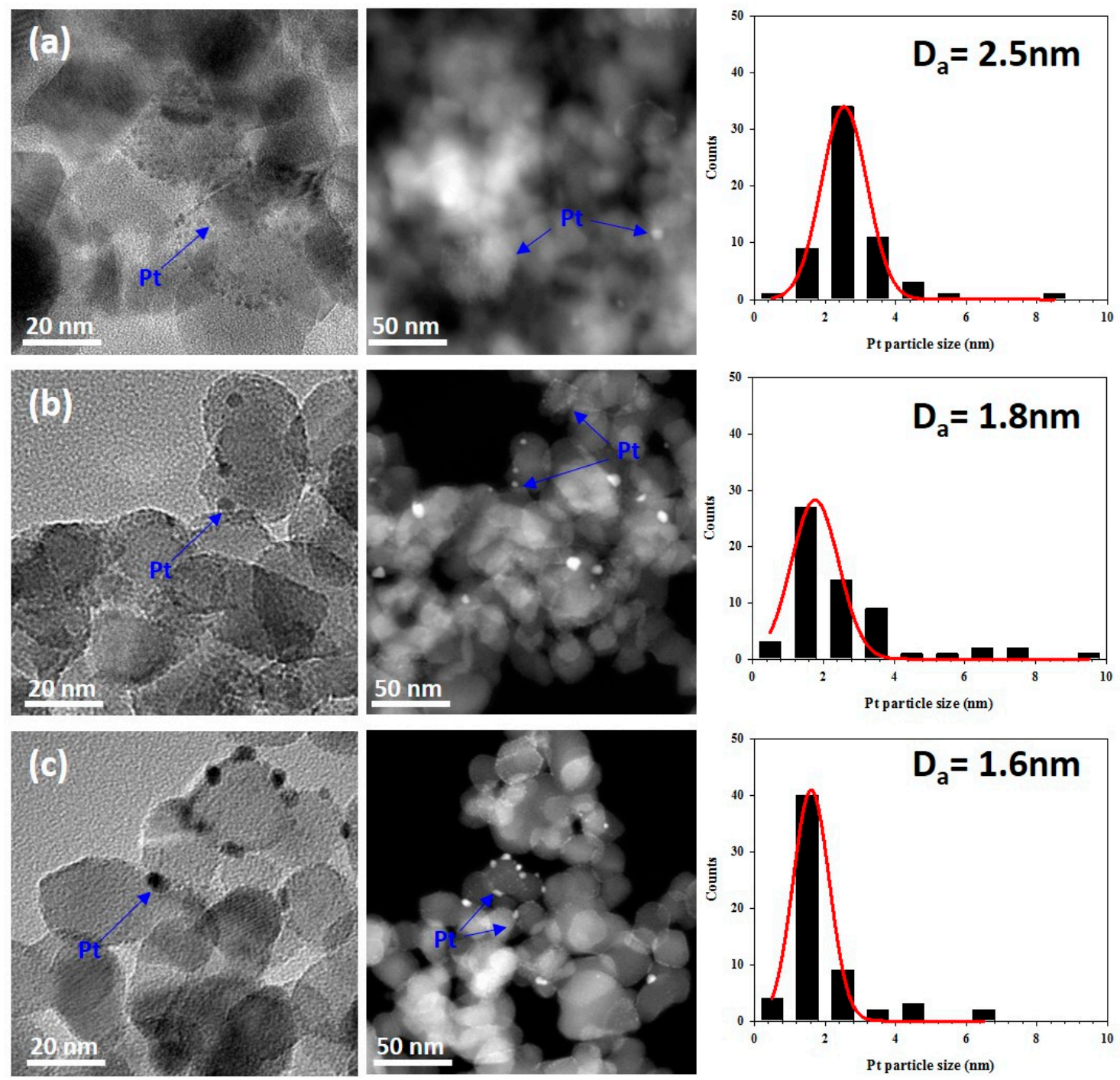

Figure 2. FE-TEM and S-TEM images and platinum particle size distributions of $\mathrm{Pt}-\mathrm{W}[\mathrm{x}] / \mathrm{TiO}_{2}$ catalysts: (a) $\mathrm{Pt}-\mathrm{W}[0] / \mathrm{TiO}_{2}$, (b) $\mathrm{Pt}-\mathrm{W}[3] / \mathrm{TiO}_{2}$, and (c) $\mathrm{Pt}-\mathrm{W}[7] / \mathrm{TiO}_{2}$.

Table 3 shows the results of the $\mathrm{CO}$ pulse chemisorption analysis for the $\mathrm{Pt}-\mathrm{W}[\mathrm{x}] / \mathrm{TiO}_{2}$ catalysts. When the tungsten loading amount on the catalyst was less than $3 \mathrm{wt} . \%$, the dispersion and particle size of platinum were not significantly affected. However, when the loading amount was more than $5 \mathrm{wt} . \%$, the dispersion of platinum drastically decreased and the platinum particle size dramatically increased. However, the average particle sizes of platinum obtained from the CO pulse chemisorption and TEM analyses are considerably different. According to the results of the TEM analysis, the amount of $\mathrm{CO}$ chemically adsorbed on platinum during $\mathrm{CO}$ pulse chemisorption decreased owing to partial blocking of the platinum particles by WOx. 

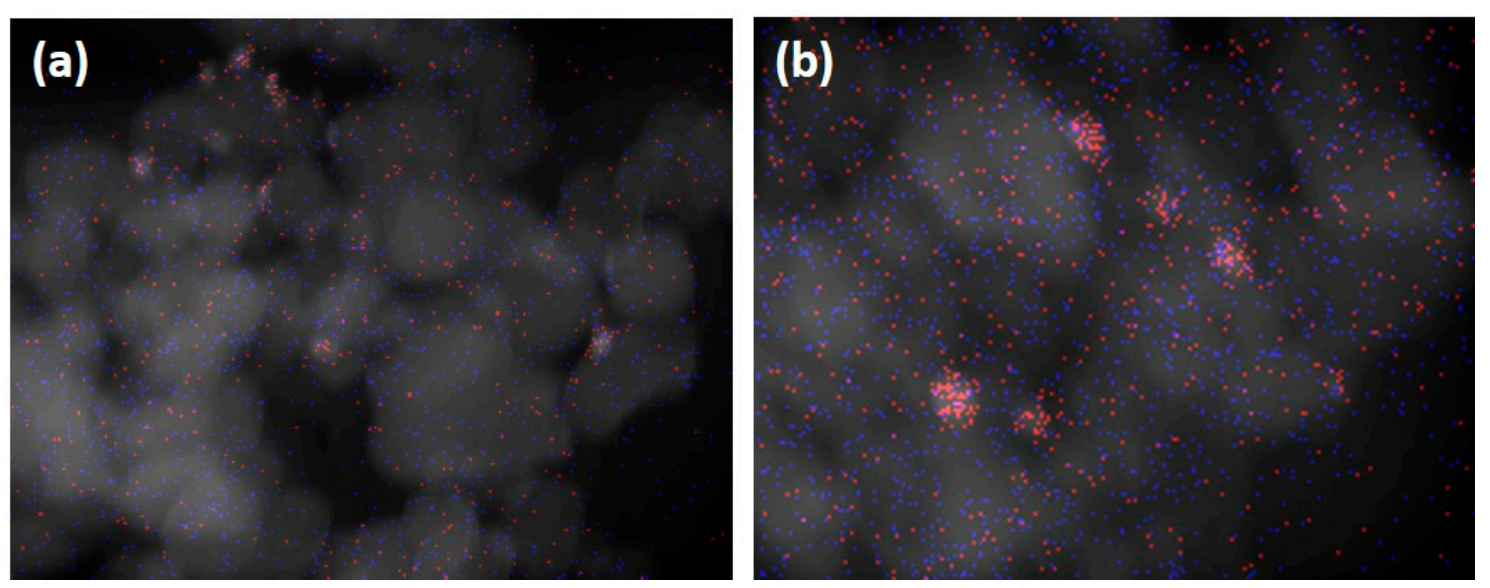

Figure 3. EDS mapping of the distribution of platinum (red) and tungsten (blue) in the $\mathrm{Pt}-\mathrm{W}[\mathrm{x}] / \mathrm{TiO}_{2}$ catalysts: (a) $\mathrm{Pt}-\mathrm{W}[3] / \mathrm{TiO}_{2}$ and (b) $\mathrm{Pt}-\mathrm{W}[7] / \mathrm{TiO}_{2}$.

Table 3. Particle size and dispersion of platinum as determined by $\mathrm{CO}$ pulse chemisorption and TEM analysis.

\begin{tabular}{|c|c|c|c|c|}
\hline \multirow[b]{2}{*}{ Sample } & \multirow{2}{*}{ Pt Loading (wt.\%) ${ }^{a}$} & \multirow{2}{*}{ Pt Dispersion (\%) ${ }^{b}$} & \multicolumn{2}{|c|}{ Pt Particle Size } \\
\hline & & & $(\mathrm{nm})^{b}$ & $(\mathrm{~nm})^{\mathrm{c}}$ \\
\hline $\mathrm{W}[0]$ & 0.95 & 22.1 & 5.1 & 2.5 \\
\hline$W[1]$ & 0.98 & 17.1 & 6.6 & - \\
\hline$W[3]$ & 1.03 & 19.8 & 5.7 & 1.8 \\
\hline $\mathrm{W}[5]$ & 0.94 & 8.8 & 12.8 & - \\
\hline W[7] & 1.08 & 6.1 & 18.5 & 1.6 \\
\hline
\end{tabular}

${ }^{\mathrm{a}} \mathrm{Pt}$ loadings were calculated from ICP-MS (Inductively Coupled Plasma Mass Spectrometer). ${ }^{\mathrm{b}} \mathrm{Pt}$ dispersions and particle sizes were calculated from CO pulse chemisorption. ${ }^{\mathrm{C}} \mathrm{Pt}$ particle sizes from S-TEM images.

Figure 4 shows the $\mathrm{H}_{2}-\mathrm{TPR}\left(\mathrm{H}_{2}\right.$ temperature-programmed reduction) results for the $\mathrm{Pt}-\mathrm{W}[\mathrm{x}] / \mathrm{TiO}_{2}$ catalysts. For the catalyst without tungsten, the reduction peaks produced by the strong metal-support interaction (SMSI) effects of $\mathrm{PtOx}$ and $\mathrm{Pt}-\mathrm{TiO}_{2}$ appeared at 60 and $170^{\circ} \mathrm{C}$, respectively, and the surface reduction peak of $\mathrm{TiO}_{2}$ appeared at $320^{\circ} \mathrm{C}$ [17]. In contrast, for the catalysts containing tungsten, a new peak was detected at approximately $230{ }^{\circ} \mathrm{C}$, which was considered to be generated by the $\mathrm{Pt}-\mathrm{W}$ interaction. The reduction peak resulting from the SMSI effect of $\mathrm{Pt}-\mathrm{TiO}_{2}$ shifted to higher temperatures when up to $3 \mathrm{wt} . \%$ tungsten was added, but then shifted back to lower temperatures when more than $3 \mathrm{wt} . \%$ tungsten was added. This change may have resulted from overloading of tungsten, thereby increasing the $\mathrm{W}-\mathrm{Ti}$ interaction and decreasing the $\mathrm{Pt}-\mathrm{TiO}_{2}$ interaction [18].

Figure 5 shows the $\mathrm{NH}_{3}$-TPD $\left(\mathrm{NH}_{3}\right.$ temperature-programmed desorption) curves of the $\mathrm{Pt}-\mathrm{W}[\mathrm{x}] / \mathrm{TiO}_{2}$ catalysts. The $\mathrm{NH}_{3}-\mathrm{TPD}$ curves can be deconvoluted into three peaks corresponding to weak, medium, and strong acid sites. The acid site densities of the catalysts with increasing tungsten content were calculated from the peak areas (Table 4). As the tungsten content increased, the total number of acid sites decreased. However, the amount of strong acid sites increased with increasing tungsten content, and broad peaks were detected at 460 and $480{ }^{\circ} \mathrm{C}$ in catalysts containing more than $3 \mathrm{wt} . \%$ tungsten. Thus, as the tungsten loading amount on the catalyst increased, $\mathrm{WOx}$ covered $\mathrm{TiO}_{2}$, thereby decreasing the amount of $\mathrm{TiO}_{2}$-related weak and medium acid sites and increasing the amount of WOx-related strong acid sites [19]. 


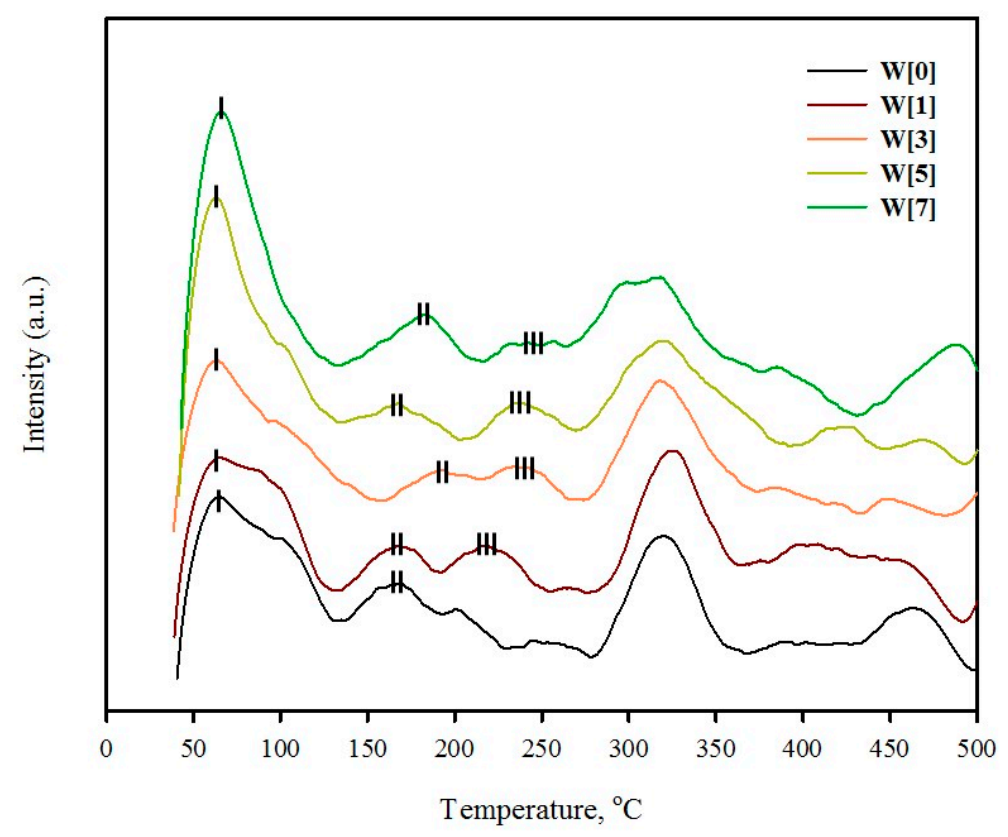

Figure 4. $\mathrm{H}_{2}-\mathrm{TPR}$ profiles of $\mathrm{Pt}-\mathrm{W}[\mathrm{x}] / \mathrm{TiO}_{2}$ catalysts.

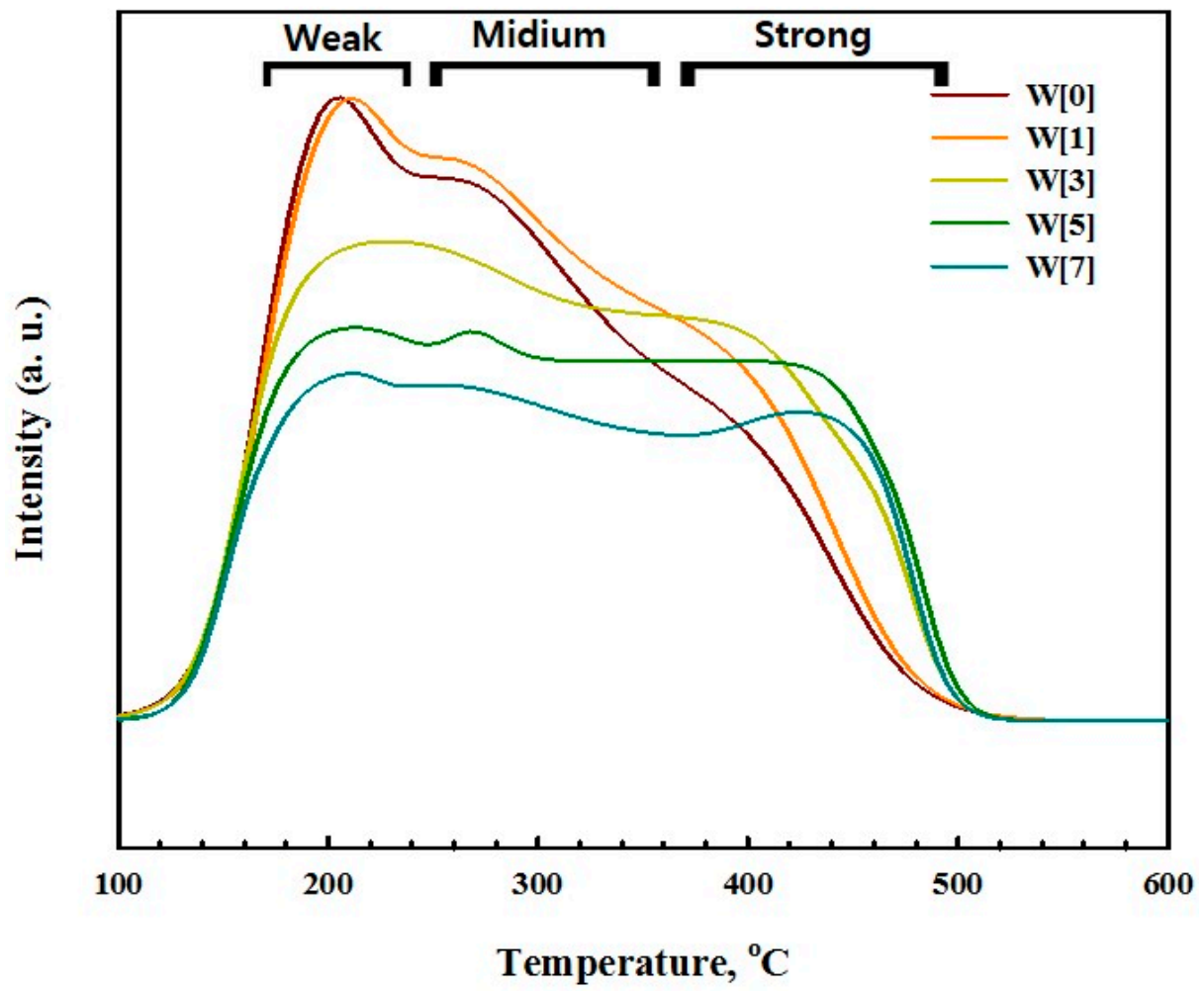

Figure 5. $\mathrm{NH}_{3}-\mathrm{TPD}$ profiles of $\mathrm{Pt}-\mathrm{W}[\mathrm{x}] / \mathrm{TiO}_{2}$ catalysts. 
Table 4. Density of acid sites on $\mathrm{Pt}-\mathrm{W}[\mathrm{x}] / \mathrm{TiO}_{2}$ catalysts as determined by $\mathrm{NH}_{3}-\mathrm{TPD}$ analysis.

\begin{tabular}{ccccc}
\hline \multirow{2}{*}{ Sample } & \multicolumn{4}{c}{ Acid Site Density $\left(\mathbf{m m o l}_{\mathbf{N H} 3} \mathbf{~} \mathbf{C a t}{ }^{-\mathbf{1}}\right)$} \\
\cline { 2 - 5 } & Weak & Medium & Strong & Total \\
\hline W[0] & 0.078 & 0.080 & 0.071 & 0.229 \\
W[1] & 0.088 & 0.069 & 0.086 & 0.243 \\
W[3] & 0.083 & 0.059 & 0.091 & 0.233 \\
W[5] & 0.059 & 0.052 & 0.098 & 0.209 \\
W[7] & 0.057 & 0.046 & 0.073 & 0.176 \\
\hline
\end{tabular}

To investigate the relative concentrations of Brønsted and Lewis acid sites on the surfaces of the $\mathrm{Pt}-\mathrm{W}[\mathrm{x}] / \mathrm{TiO}_{2}$ catalysts, FT-IR (Fourier transform infrared) analyses were performed by adsorbing pyridine at $200{ }^{\circ} \mathrm{C}$. At Brønsted acid sites, pyridine is adsorbed as a pyridinium ion after accepting a proton, whereas it is adsorbed as covalently bonded pyridine at Lewis acid sites via electron-pair sharing $[20,21]$. Figure 6 shows the FT-IR spectra of the pyridine-adsorbed $\mathrm{Pt}-\mathrm{W}[\mathrm{x}] / \mathrm{TiO}_{2}$ catalysts. Generally, peaks corresponding to the Brønsted acid sites appear at 1545 and $1640 \mathrm{~cm}^{-1}$, whereas those corresponding to the Lewis acid sites appear at 1435 and $1598 \mathrm{~cm}^{-1}$ [22,23]. Brønsted acid sites were not detected in the catalyst without tungsten. However, a peak assigned to the Brønsted acid sites $\left(1640 \mathrm{~cm}^{-1}\right)$ slightly increased with increasing tungsten content. Table 5 shows the IR-band area and ratio ( $\mathrm{B} / \mathrm{L}$ ratio) of the Brønsted and Lewis acid sites with increasing tungsten content in $\mathrm{Pt}-\mathrm{W}[\mathrm{x}] / \mathrm{TiO}_{2}$. Assuming the adsorption sites of pyridine are identical to those of ammonia, the densities of the Brønsted and Lewis sites were calculated by multiplying total acid site density by $\left(\frac{\mathrm{B} / \mathrm{L}}{\mathrm{B} / \mathrm{L}+1}\right)$ and $\left(\frac{1}{\mathrm{~B} / \mathrm{L}+1}\right)$, respectively. As the tungsten content in the catalyst increased to $7 \mathrm{wt} . \%$, the peak areas of the Brønsted and Lewis acid sites increased. In addition, the B/L ratio indicated a three-fold increase in the number of Brønsted acid sites. These results reveal that tungsten loading resulted in the formation of Brønsted acid sites and a decrease in the proportion of Lewis acid sites.

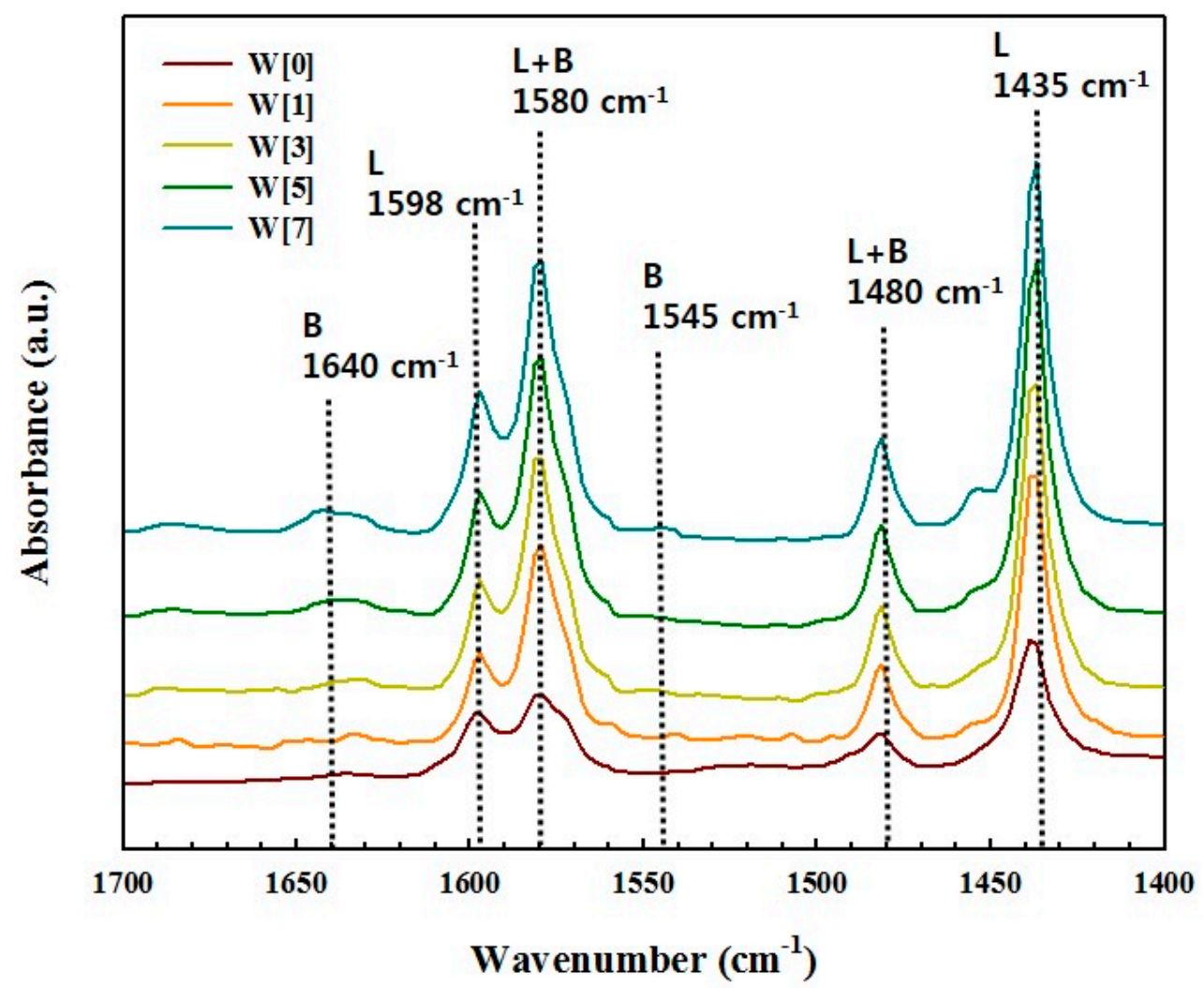

Figure 6. FT-IR spectra of $\mathrm{Pt}-\mathrm{W}[\mathrm{x}] / \mathrm{TiO}_{2}$ catalysts after pyridine adsorption and subsequent desorption at $200{ }^{\circ} \mathrm{C}$. 
Table 5. Area and area ratio (B/L ratio) of Brønsted and Lewis acid sites on $\mathrm{Pt}-\mathrm{W}[\mathrm{x}] / \mathrm{TiO}_{2}$ catalysts.

\begin{tabular}{|c|c|c|c|c|c|c|}
\hline \multirow[t]{2}{*}{ Sample } & \multirow{2}{*}{$\begin{array}{c}\text { B-Acid Area } \\
\left(1640 \mathrm{~cm}^{-1}\right)\end{array}$} & \multirow{2}{*}{$\begin{array}{l}\text { L-Acid Area } \\
\left(1435 \mathrm{~cm}^{-1}\right)\end{array}$} & \multirow[t]{2}{*}{ B/L Ratio ${ }^{b}$} & \multicolumn{3}{|c|}{$\begin{array}{l}\text { Acid Site Density } \\
\left(\mathrm{mmol}_{\mathrm{NH} 3} \mathrm{~g}_{\mathrm{Cat}}{ }^{-1}\right)\end{array}$} \\
\hline & & & & Total $^{\mathbf{a}}$ & Brønsted $^{\mathrm{c}}$ & Lewis $^{c}$ \\
\hline $\mathrm{W}[0]$ & - & 8.03 & - & 0.229 & - & - \\
\hline $\mathrm{W}[1]$ & 0.75 & 14.25 & 0.05 & 0.243 & 0.012 & 0.231 \\
\hline$W[3]$ & 0.92 & 15.95 & 0.06 & 0.233 & 0.013 & 0.220 \\
\hline$W[5]$ & 1.31 & 17.31 & 0.08 & 0.209 & 0.015 & 0.194 \\
\hline $\mathrm{W}[7]$ & 2.15 & 18.50 & 0.12 & 0.176 & 0.018 & 0.158 \\
\hline
\end{tabular}

${ }^{a}$ The acid site densities were obtained by integrating $\mathrm{NH}_{3}$-TPD curves in Figure $5 .{ }^{\mathrm{b}} \mathrm{B}, \mathrm{L}$ area and $\mathrm{B} / \mathrm{L}$ ratios were obtained from the pyridine adsorption FTIR spectroscopy results. ${ }^{\mathrm{c}}$ Brønsted and Lewis acid density were calculated using total acid density and $\mathrm{B} / \mathrm{L}$ ratio.

\subsection{Catalytic Activities of $\mathrm{Pt}-\mathrm{W}[x] / \mathrm{TiO}_{2}$ for $\mathrm{NO}$ and Soot Oxidation}

The catalytic oxidation of $\mathrm{NO}$ to $\mathrm{NO}_{2}$ is an important reaction for $\mathrm{NO}$ emitted from diesel engines, as the produced $\mathrm{NO}_{2}$ can be used as an oxidant in soot oxidation. Figure 7a illustrates the NO oxidation results over the $\mathrm{Pt}-\mathrm{W}[\mathrm{x}] / \mathrm{TiO}_{2}$ catalysts. The amount of $\mathrm{NO}_{2}$ produced by $\mathrm{NO}$ oxidation increased as the content of tungsten increased at temperatures below $350{ }^{\circ} \mathrm{C}$. At $250{ }^{\circ} \mathrm{C}$, the concentration of $\mathrm{NO}_{2}$ generated increased approximately 3.5 times as the amount of tungsten in the catalysts increased to $7 \mathrm{wt} . \%$. As revealed by the $\mathrm{NH}_{3}$-TPD analysis, this phenomenon may occur because the amount of strong acid sites on the surface of the catalyst increased as the tungsten loading amount increased. Thus, the adsorption of $\mathrm{NO}$ on the catalyst surface was favored and the adsorbed NO was oxidized to $\mathrm{NO}_{2}$ on the platinum surface [14].

Next, soot oxidation by $\mathrm{NO}_{2}$ was performed by supplying 300 ppm $\mathrm{NO}_{2}, 3$ ppm $\mathrm{SO}_{2}, 10 \% \mathrm{O}_{2}$, and balance $\mathrm{N}_{2}$. Figure $7 \mathrm{~b}$ shows the experimental results over the $\mathrm{Pt}-\mathrm{W}[\mathrm{x}] / \mathrm{TiO}_{2}$ catalysts. When $1 \mathrm{wt} . \%$ tungsten was loaded on the catalyst, the activity was similar to that of the $\mathrm{Pt} / \mathrm{TiO}_{2}$ catalyst without tungsten. However, when $3 \mathrm{wt} . \%$ tungsten was loaded, the soot oxidation rate rapidly increased, and similar reaction results were also observed at tungsten loading amounts of more than $3 \mathrm{wt} . \%$. Thus, as the acidity of the catalyst surface increased, NOx was more easily absorbed. However, the addition of more than $3 \mathrm{wt} . \%$ tungsten did not significantly affect soot oxidation by $\mathrm{NO}_{2}$.

Figure $7 \mathrm{c}$ exhibits the experimental results for the reaction of $300 \mathrm{ppm} \mathrm{NO}, 3 \mathrm{ppm} \mathrm{SO}{ }_{2}, 10 \% \mathrm{O}_{2}$, and balance $\mathrm{N}_{2}$ over the $\mathrm{Pt}-\mathrm{W}[\mathrm{x}] / \mathrm{TiO}_{2}$ catalysts. Under these conditions, the soot conversion rate at $300{ }^{\circ} \mathrm{C}$ decreased in the order of $\mathrm{W}[3]>\mathrm{W}[5]>\mathrm{W}[1]>\mathrm{W}[0]>\mathrm{W}[7]$. Liu et al. explained that the acidity of the catalyst surface acts as a promoter for transferring $\mathrm{NO}_{2}$ formed on the platinum surface to soot [13]. The dependence of the soot oxidation performance on $\mathrm{NO}_{2}$ was quite high. Moreover, the experimental results for the oxidation of $\mathrm{NO}$ into $\mathrm{NO}_{2}$ (Figure 7a) and the oxidation of soot using $\mathrm{NO}_{2}$ (Figure $7 \mathrm{~b}$ ) showed that as the content of tungsten in the $\mathrm{Pt} / \mathrm{TiO}_{2}$ catalyst increased, the supply of $\mathrm{NO}_{2}$, the oxidant required for soot oxidation, increased. However, the soot oxidation results differed when $\mathrm{NO}$ was used (Figure 7c). These experimental results indicate that there was a significant variable other than $\mathrm{NO}_{2}$ production involved in the soot oxidation reaction. 

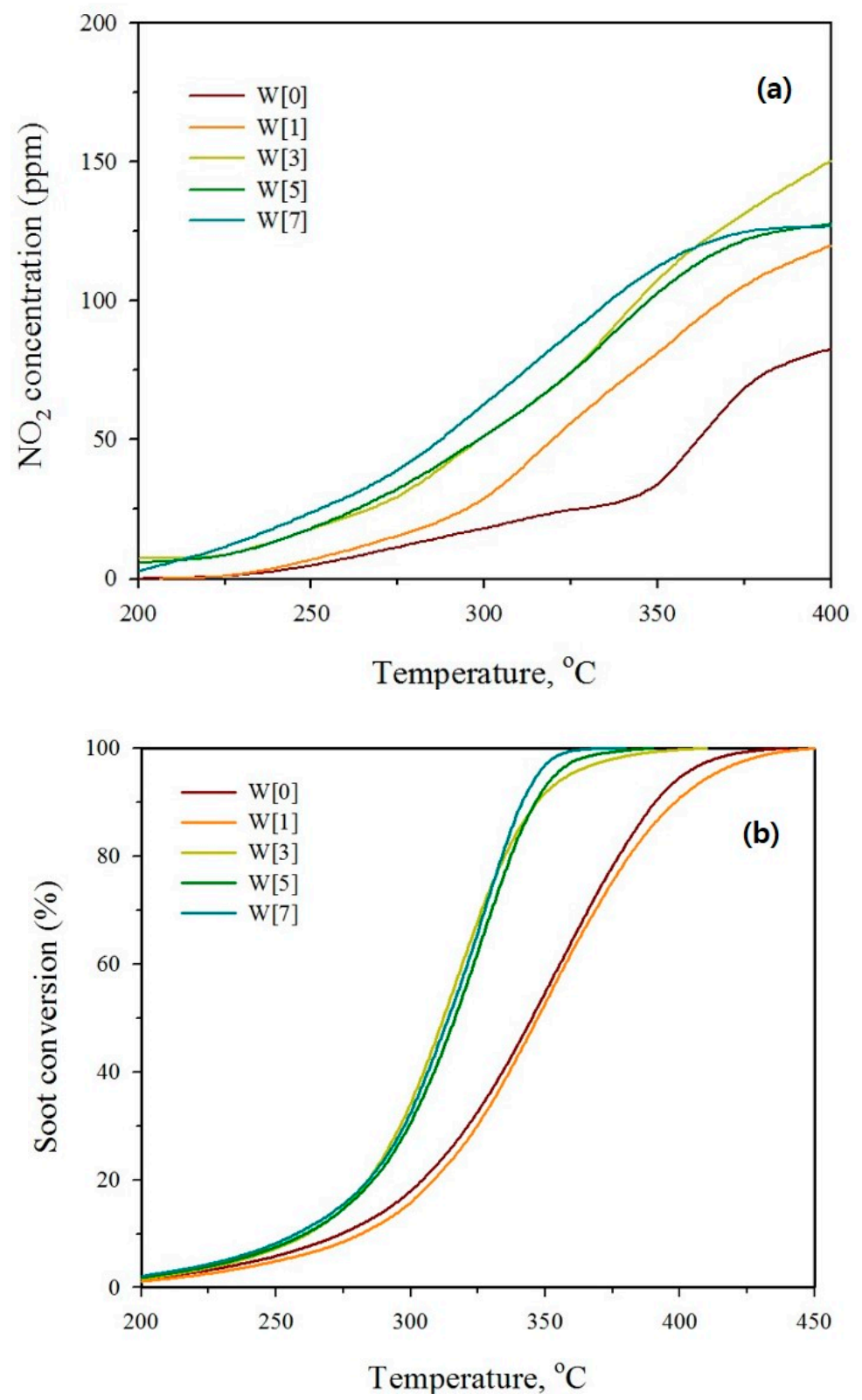

Figure 7. Cont. 


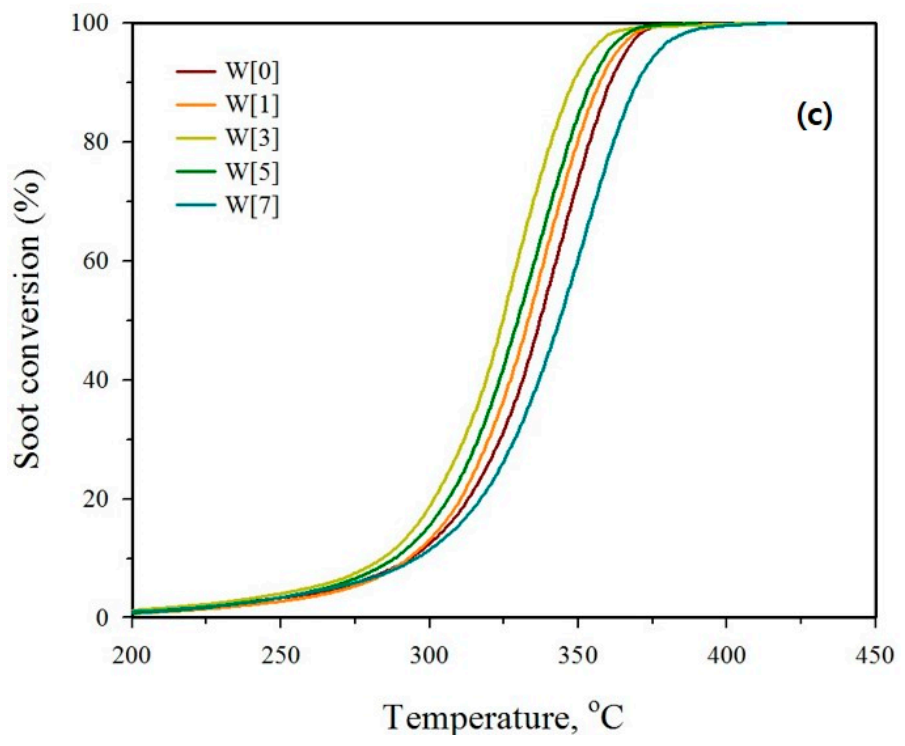

Figure 7. (a) $\mathrm{NO}_{2}$ concentration profile during the $\mathrm{NO}$ oxidation reaction over $\mathrm{Pt}-\mathrm{W}[\mathrm{x}] / \mathrm{TiO}_{2}$ catalysts. Reaction conditions: catalyst $=100 \mathrm{~g} / \mathrm{L}$; reactant gas $=300 \mathrm{ppm} \mathrm{NO}, 3 \mathrm{ppm} \mathrm{SO}, 10 \% \mathrm{O}_{2}, 5 \% \mathrm{H}_{2} \mathrm{O}$, and $\mathrm{N}_{2}$ balance; flow $=1.0 \mathrm{~L} / \mathrm{min}$; GHSV $=50,000 \mathrm{~h}^{-1}$. (b) Soot oxidation performance of $\mathrm{Pt}-\mathrm{W}[\mathrm{x}] / \mathrm{TiO}_{2}$ catalysts using $\mathrm{NO}_{2}$. Reaction conditions: catalyst/soot $=8: 2$; reactant gas $=300 \mathrm{ppm} \mathrm{\textrm {NO } _ { 2 } , 3 \text { ppm SO}}, 10 \% \mathrm{O}_{2}$, $5 \% \mathrm{H}_{2} \mathrm{O}$, and $\mathrm{N}_{2}$ balance; total flow $=0.1 \mathrm{~L} / \mathrm{min} ; \mathrm{GHSV}=50,000 \mathrm{~h}^{-1}$. (c) Soot oxidation performance of $\mathrm{Pt}-\mathrm{W}[\mathrm{x}] / \mathrm{TiO}_{2}$ catalysts using $\mathrm{NO}$. Reaction conditions: catalyst/soot $=8: 2$; reactant gas $=300 \mathrm{ppm} \mathrm{NO}$, 3 ppm $\mathrm{SO}_{2}, 10 \% \mathrm{O}_{2}, 5 \% \mathrm{H}_{2} \mathrm{O}$, and $\mathrm{N}_{2}$ balance; total flow $=0.1 \mathrm{~L} / \mathrm{min} ; \mathrm{GHSV}=50,000 \mathrm{~h}^{-1}$.

Figure 8 shows illustrations of the soot oxidation process using NO based on the analysis of the catalyst properties. As shown in Figure $8 \mathrm{a}, \mathrm{NO}_{2}$ produced on the platinum surface migrates to soot when the platinum and the soot are adjacent to each other, thereby leading to rapid soot oxidation. Thus, the $\mathrm{Pt}-\mathrm{W}[3] / \mathrm{TiO}_{2}$ catalyst, which is loaded with an appropriate amount of tungsten, is considered advantageous for soot oxidation using NO. In contrast, as shown in Figure 8b, when platinum was completely covered by WOx, gaseous $\mathrm{NO}$ could easily react with platinum to generate $\mathrm{NO}_{2}$, but contact between soot and platinum, the active site, is difficult. Therefore, soot oxidation is relatively unlikely to occur. Therefore, NO oxidation was dominant in the catalyst loaded with $7 \mathrm{wt}$. \% tungsten, but the soot oxidation rate using $\mathrm{NO}$ was relatively low.
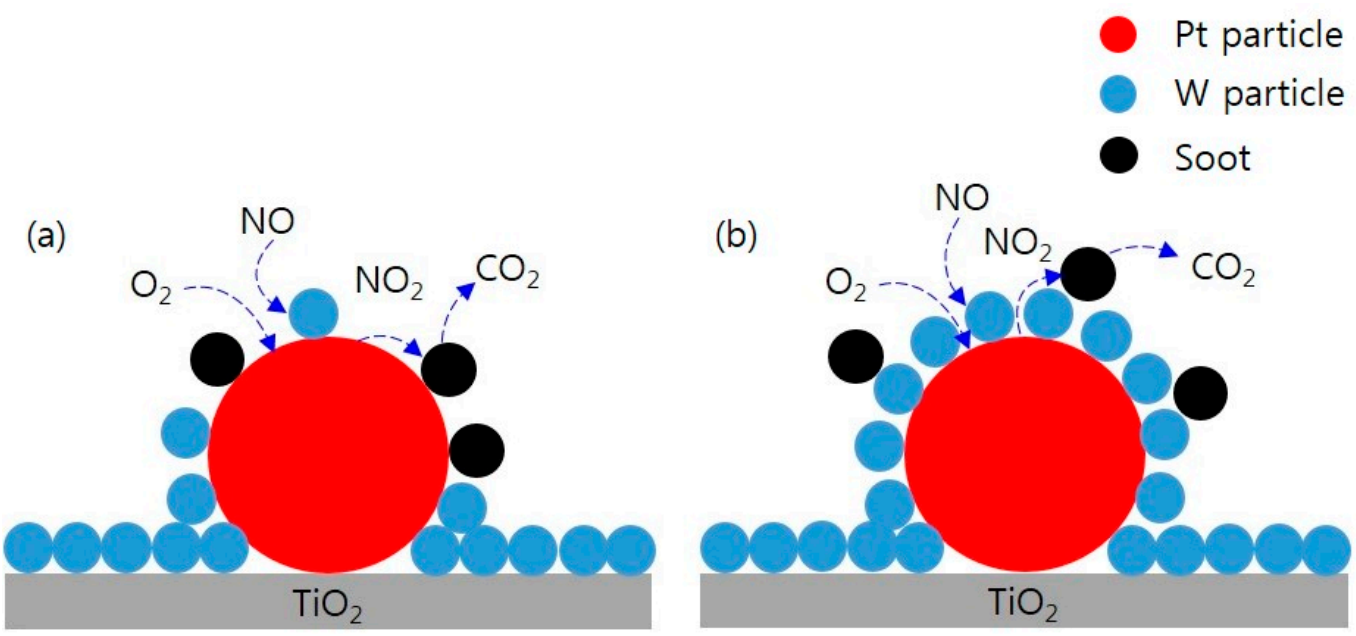

Figure 8. Illustration of catalysts covered with tungsten oxide as a function of the tungsten content. 
Figure 9 displays the temperature at which soot conversion rates of $10 \%\left(\mathrm{~T}_{10}\left({ }^{\circ} \mathrm{C}\right)\right)$ and $20 \%$ $\left(\mathrm{T}_{20}\left({ }^{\circ} \mathrm{C}\right)\right)$ are achieved, as well as the respective regression curves according to the tungsten content of the catalyst. When the catalyst was loaded with $3 \mathrm{wt} . \%$ tungsten, the lowest $\mathrm{T}_{10}\left({ }^{\circ} \mathrm{C}\right)$ and $\mathrm{T}_{20}\left({ }^{\circ} \mathrm{C}\right)$ values of 284 and $301{ }^{\circ} \mathrm{C}$, respectively, were obtained. The regression curves suggest that a tungsten loading of 3.5-4.0 wt.\% will result in the lowest temperature for soot conversion.

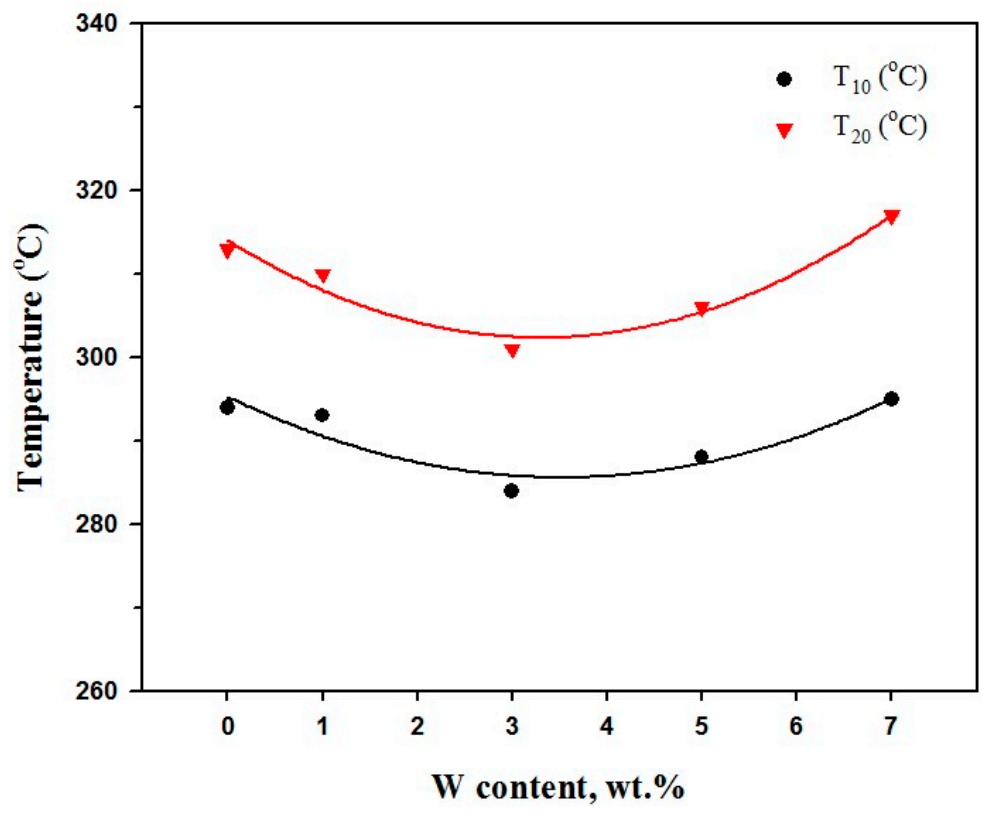

Figure 9. Temperatures corresponding to soot conversion rates of $10 \%\left(\mathrm{~T}_{10}\left({ }^{\circ} \mathrm{C}\right)\right)$ and $20 \%\left(\mathrm{~T}_{20}\left({ }^{\circ} \mathrm{C}\right)\right)$ as a function of the tungsten content in $\mathrm{Pt}-\mathrm{W}[\mathrm{x}] / \mathrm{TiO}_{2}$ catalysts. Reaction conditions: catalyst/soot = 8:2; reactant gas $=300 \mathrm{ppm} \mathrm{NO}, 3$ ppm $\mathrm{SO}_{2}, 10 \% \mathrm{O}_{2}, 5 \% \mathrm{H}_{2} \mathrm{O}$, and $\mathrm{N}_{2}$ balance; total flow $=0.1 \mathrm{~L} / \mathrm{min}$; $\mathrm{GHSV}=50,000 \mathrm{~h}^{-1}$.

\section{Materials and Methods}

\subsection{Catalyst Preparation}

Degussa P-25 was used as the $\mathrm{TiO}_{2}$ support, ammonium paratungstate (APT, $\left.\left[\left(\mathrm{NH}_{4}\right) 10\left(\mathrm{H}_{2} \mathrm{~W}_{12} \mathrm{O}_{42}\right) \cdot 4 \mathrm{H}_{2} \mathrm{O}\right]\right)$ was used as a precursor for tungsten, and platinum was obtained from a platinum solution (A type, 16.6\%, SNS Co., Hwa-seong, Korea). In this study, the content of platinum on the support was fixed at $1 \mathrm{wt} . \%$, and the content of tungsten was $0-7 \mathrm{wt} . \%$. The Pt-W[x]/TiO $\mathrm{T}_{2}$ catalysts (where $\mathrm{x}$ is the content of tungsten in wt.\%) were prepared as follows. Firstly, calculated APT was added to solution of oxalic acid dehydrate $\left(\left[\mathrm{HO}_{2} \mathrm{CCO}_{2} \mathrm{H} \cdot 2 \mathrm{H}_{2} \mathrm{O}\right]\right.$, Sigma-Aldrich, St. Louis, $\mathrm{MO}$, USA). The mixture was stirred at $300 \mathrm{rpm}$ for $10 \mathrm{~min}$ until clear solution formed. An APT solution was loaded on $10 \mathrm{~g}$ of $\mathrm{TiO}_{2}$ by an incipient wetness method and then dried at $100{ }^{\circ} \mathrm{C}$ for $5 \mathrm{~h}$ to prepare $\mathrm{W}[\mathrm{x}] / \mathrm{TiO}_{2}$ powder. Next, the calculated platinum solution was loaded on the $10 \mathrm{~g}$ of dried $\mathrm{W}[\mathrm{x}] / \mathrm{TiO}_{2}$ powder by the incipient wetness method. The $\mathrm{Pt}-\mathrm{W}[\mathrm{x}] / \mathrm{TiO}_{2}$ catalyst was dried at $100{ }^{\circ} \mathrm{C}$ for $24 \mathrm{~h}$ and then calcined in an air atmosphere at $500{ }^{\circ} \mathrm{C}$ for $4 \mathrm{~h}$ using a calcination furnace at a heating rate of $1{ }^{\circ} \mathrm{C} / \mathrm{min}$.

For $\mathrm{NO}$ oxidation, the $\mathrm{Pt}-\mathrm{W}[\mathrm{x}] / \mathrm{TiO}_{2}$ catalyst powder was mixed with distilled water (catalyst $(\mathrm{g}) /$ water $(\mathrm{g})=0.5$ ) and milled for $30 \mathrm{~min}$ using a mortar to prepare a slurry. Next, the catalyst slurry was coated on a cordierite honeycomb (400 cells per square inch (cpsi) with a height of $0.6 \mathrm{~cm}$ ) at a rate of $100 \mathrm{~g} / \mathrm{L}$. SEM images of the non-catalyst coating and catalyst coating samples are shown in Figure S1, and the properties of cordierite honeycomb are shown in the Table S1. 


\subsection{Experimental Apparatus and Evaluation Method}

\subsubsection{NO Oxidation}

A tube-type quartz reactor with an inner diameter of $1.6 \mathrm{~cm}$ was used to confirm the NO oxidation performance of the $\mathrm{Pt}-\mathrm{W}[\mathrm{x}] / \mathrm{TiO}_{2}$ catalysts. The prepared honeycomb catalysts were fixed in the quartz reactor, and the $\mathrm{NO}$ and $\mathrm{NO}_{2}$ concentrations after the reaction were analyzed using non-dispersive infrared spectroscopy (Fuji Co., Tokyo, Japan). The experimental conditions for NO oxidation were as follows: $300 \mathrm{ppm} \mathrm{NO}, 3 \mathrm{ppm} \mathrm{SO}, 10 \% \mathrm{O}_{2}, 5 \% \mathrm{H}_{2} \mathrm{O}$, and $\mathrm{N}_{2}$ balance. The total flow rate of the reactants was $1.0 \mathrm{~L} / \mathrm{min}\left(\mathrm{GHSV}=50,000 \mathrm{~h}^{-1}\right)$.

\subsubsection{Soot Oxidation}

A tube-type quartz reactor with an inner diameter of $0.4 \mathrm{~cm}$ was used to confirm the soot oxidation performance of the $\mathrm{Pt}-\mathrm{W}[\mathrm{x}] / \mathrm{TiO}_{2}$ catalysts. The $\mathrm{Pt}-\mathrm{W}[\mathrm{x}] / \mathrm{TiO}_{2}$ catalyst powder and soot were mixed (catalyst $(\mathrm{g}) /$ soot $(\mathrm{g})=4)$ using a mortar for $30 \mathrm{~min}$ to ensure good contact. The model soot used in the experiment was Printex U (Degussa, 20-30 nm). The experiment was carried out at $200-450{ }^{\circ} \mathrm{C}$ under the following reaction conditions: $300 \mathrm{ppm} \mathrm{NO}$ or $\mathrm{NO}_{2}, 3 \mathrm{ppm} \mathrm{SO}_{2}, 10 \% \mathrm{O}_{2}, 5 \% \mathrm{H}_{2} \mathrm{O}$, and $\mathrm{N}_{2}$ balance. The total flow rate of the reactants was $100 \mathrm{~mL} / \mathrm{min}\left(\mathrm{GHSV}=50,000 \mathrm{~h}^{-1}\right)$. The concentration of $\mathrm{CO}_{2}$ generated after soot oxidation was measured at the outlet using gas chromatography $(7890 \mathrm{~A}$, Agilent Technology Co, Santa Clara, CA., USA) with a thermal conductivity detector and a capillary column (Carboxen 1010 PLOT, $30 \mathrm{~m} \times 0.533 \mathrm{~mm}$, SUPELCO Co., St. Louis, MO, USA).

\subsection{Catalyst Characterization}

The BET surface areas and pore characteristics of the $\mathrm{Pt}-\mathrm{W}[\mathrm{x}] / \mathrm{TiO}_{2}$ catalysts were measured using a Micromeritics ASAP 2020 instrument.

XRD (D/max-2200/PC, Rigaku Co., Tokyo, Japan) with CuK $\alpha$ radiation was conducted at $40 \mathrm{kV}$ and $200 \mathrm{~mA}$ in the $2 \theta$ range of $10-100^{\circ}$ to confirm the crystal structure as the tungsten content of the catalyst increased.

To determine the platinum particle size, tungsten loading state, and dispersion of the catalyst, FE-TEM (JEM-2200FS, JEOL Co., Tokyo, Japan) was used. To analyze the size and distribution of platinum particles on $\mathrm{TiO}_{2}$ accurately, S-TEM was used. The elemental composition of the catalyst surface was analyzed by EDS mapping. For these measurements, the sample was dispersed in ethanol and prepared on a copper grid (300 mesh).

CO pulse chemisorption, $\mathrm{H}_{2}$-TPR, and $\mathrm{NH}_{3}$-TPD were performed using a Micromeritics Autochem 2920 instrument. CO pulse chemisorption was performed to determine the platinum particle size and dispersion of the catalyst. The catalyst was subjected to reduction treatment by maintaining a temperature of $300{ }^{\circ} \mathrm{C}$ for $1 \mathrm{~h}$ while injecting a mixed gas of $10 \% \mathrm{H}_{2} / \mathrm{Ar}$. Then, He gas was injected for $30 \mathrm{~min}$ to remove adsorbed hydrogen. Next, the temperature was lowered to room temperature, and $10 \% \mathrm{CO} / \mathrm{He}$ was pulse injected at a flow rate of $50 \mathrm{~mL} / \mathrm{min}$ to measure the particle size and dispersion of platinum based on the amount of adsorbed CO.

$\mathrm{H}_{2}$-TPR analysis was performed to determine the reducing ability of the catalyst according to temperature. The calcined sample was heated to $800^{\circ} \mathrm{C}$ at a heating rate of $5{ }^{\circ} \mathrm{C} / \mathrm{min}$ while injecting a mixed gas of $10 \% \mathrm{H}_{2} / \mathrm{Ar}$. $\mathrm{NH}_{3}$-TPD was conducted to analyze the acid sites in the catalyst. The calcined sample was activated by maintaining a temperature of $300{ }^{\circ} \mathrm{C}$ for $1 \mathrm{~h}$ under a mixed gas of $10 \% \mathrm{H}_{2} / \mathrm{Ar}$. After exposure to a mixed gas of $15 \% \mathrm{NH}_{3} / \mathrm{He}$ at room temperature for $1 \mathrm{~h}$, the temperature of the sample was raised to $100{ }^{\circ} \mathrm{C}$ to desorb any $\mathrm{NH}_{3}$ physically adsorbed on the surface of the catalyst, and then $\mathrm{He}$ was injected for $30 \mathrm{~min}$. Subsequently, the analysis was conducted by raising the sample temperature to $600{ }^{\circ} \mathrm{C}$ at $10^{\circ} \mathrm{C} / \mathrm{min}$ while flowing He at $50 \mathrm{~mL} / \mathrm{min}$.

To determine the distribution of Brønsted and Lewis acid sites on the catalyst, pyridine was adsorbed, and FT-IR spectra (FTLA2000-104, ABB Co., Zürich, Switzerland) were obtained. The sample was mounted on a diffuse reflection infrared Fourier transform (DRIFT) cell, and a background IR 
spectrum was obtained after degassing in a $300{ }^{\circ} \mathrm{C}$ vacuum atmosphere for $2 \mathrm{~h}$. Next, the pyridine solution was injected into the DRIFT cell using a syringe, and pyridine molecules were adsorbed on the catalyst. The adsorption process was allowed to proceed at $200{ }^{\circ} \mathrm{C}$ for $30 \mathrm{~min}$ to saturate the acid sites on the catalyst surface with pyridine, and IR spectra were obtained.

\section{Conclusions}

In this study, a Pt-W[x]/ $\mathrm{TiO}_{2}$ catalyst showing excellent soot oxidation was developed. As the content of tungsten in the Pt-W[x]/TiO ${ }_{2}$ catalyst increased, the amount of strong acid sites and Brønsted acid sites increased, and the catalytic activity for the oxidation of $\mathrm{NO}$ to $\mathrm{NO}_{2}$ increased. The catalysts with $3 \mathrm{wt} . \%$ or more tungsten showed similar activities for soot oxidation by $\mathrm{NO}_{2}$. In contrast, the catalyst loaded with $3 \mathrm{wt} . \%$ tungsten showed the highest activity for soot oxidation using NO. Although increased oxidation of $\mathrm{NO}$ to $\mathrm{NO}_{2}$ occurred at higher tungsten loadings, the surface of the active metal, platinum, was covered by WOx, making it difficult to deliver the produced $\mathrm{NO}_{2}$ to soot and thus lowering the reaction activity. We confirmed that an appropriate surface acidity and coverage of platinum by tungsten were important in the $\mathrm{Pt}-\mathrm{W}[\mathrm{x}] / \mathrm{TiO}_{2}$ catalysts for effective soot oxidation. In this study, we found that the $\mathrm{Pt}-\mathrm{W}[3] / \mathrm{TiO}_{2}$ catalyst showed the highest rate of soot oxidation.

Supplementary Materials: The following are available online at http://www.mdpi.com/2073-4344/10/11/1283/s1, Figure S1: SEM image of the honeycomb sample; (a) Non-catalyst coating (b) catalyst coating (100 g/L), Table S1: Properties of the honeycomb using the catalyst coating.

Author Contributions: D.-k.O. (methodology, data curation, writing original draft preparation, formal analysis), Y.-J.L. (supervision, investigation, funding acquisition), K.-Y.L. (supervision), and J.-S.P. (conceptualization, writing, reviewing, and editing, project administration). All authors have read and agreed to the published version of the manuscript.

Funding: This research was funded by the CEFV (Center for Environmentally Friendly Vehicle) as Global-Top Project of KMOE (Ministry of Environment, Korea).

Acknowledgments: This research was supported by the CEFV (Center for Environmentally Friendly Vehicle) as Global-Top Project of KMOE (Ministry of Environment, Korea).

Conflicts of Interest: The authors declare no conflict of interest.

\section{References}

1. Caliskan, H.; Mori, K. Environmental, Enviroeconomic and Enhanced Thermodynamic Analyses of a Diesel Engine with Diesel Oxidation Catalyst (DOC) and Diesel Particulate Filter (DPF) after Treatment Systems. Energy 2017, 128, 128-144. [CrossRef]

2. Jiao, P.; Li, Z.; Shen, B.; Zhang, W.; Kong, X.; Jiang, R. Research of DPF Regeneration with NOx-PM Coupled Chemical Reaction. Appl. Therm. Eng. 2017, 110, 737-745. [CrossRef]

3. Birch, M.E.; Cary, R.A. Elemental Carbon-Based Method for Monitoring Occupational Exposures to Particulate Diesel Exhaust. Aerosol Sci. Technol. 1996, 25, 221-241. [CrossRef]

4. Ko, J.; Jin, D.; Jang, W.; Myung, C.L.; Kwon, S.; Park, S. Comparative Investigation of NOx emission Characteristics from a Euro 6-Compliant Diesel Passenger Car over the NEDC and WLTC at Various Ambient Temperatures. Appl. Energy 2017, 187, 652-662. [CrossRef]

5. Görsmann, C. Catalytic Coatings for Active and Passive Diesel Particulate Filter Regeneration. Monatsh. Chem. 2005, 136, 91-105. [CrossRef]

6. Kandylas, I.P.; Koltsakis, G.C. $\mathrm{NO}_{2}$-Assisted Regeneration of Diesel Particulate Filters: A Modeling Study. Ind. Eng. Chem. Res. 2002, 41, 2115-2123. [CrossRef]

7. Choi, B.; Lee, K.-S. LNT/CDPF Catalysts for Simultaneous Removal of NOx and PM from Diesel Vehicle Exhaust. Chem. Eng. J. 2014, 240, 476-486. [CrossRef]

8. Oi-Uchisawa, J.; Wang, S.; Nanba, T.; Ohi, A.; Obuchi, A. Improvement of Pt Catalyst for Soot Oxidation Using Mixed Oxide as a Support. Appl. Catal. B 2003, 44, 207-215. [CrossRef]

9. Matarrese, R.; Castoldi, L.; Lietti, L.; Forzatti, P. Soot Combustion: Reactivity of Alkaline and Alkaline Earth Metal Oxides in Full Contact with Soot. Catal. Today 2008, 136, 11-17. [CrossRef] 
10. Krishna, K.; Bueno-López, A.; Makkee, M.; Moulijn, J.A. Potential Rare-Earth Modified $\mathrm{CeO}_{2}$ Catalysts for Soot Oxidation Part II: Characterisation and Catalytic Activity with $\mathrm{NO}+\mathrm{O}_{2}$. Appl. Catal. B 2007, 75, $201-209$. [CrossRef]

11. Liu, S.; Wu, X.; Weng, D.; Li, M.; Lee, H.-R. Combined Promoting Effects of Platinum and $\mathrm{MnOx}_{-}-\mathrm{CeO}_{2}$ Supported on Alumina on NOx-Assisted Soot Oxidation: Thermal Stability and Sulfur Resistance. Chem. Eng. J. 2012, 203, 25-35. [CrossRef]

12. Liu, S.; Wu, X.; Weng, D.; Li, M.; Ran, R. Roles of Acid Sites on Pt/H-ZSM5 Catalyst in Catalytic Oxidation of Diesel Soot. ACS Catal. 2015, 5, 909-919. [CrossRef]

13. Gao, Y.; Yang, W.; Wu, X.; Liu, S.; Weng, D.; Ran, R. Controllable Synthesis of Supported Platinum Catalysts: Acidic Support Effect and Soot Oxidation Catalysis. Catal. Sci. Technol. 2017, 7, 3268-3274. [CrossRef]

14. Liu, Z.; Lu, Y.; Yuan, L.; Ma, L.; Zheng, L.; Zhang, J.; Hu, T. Selective Catalytic Reduction of NOx with $\mathrm{H}_{2}$ over $\mathrm{WO}_{3}$ Promoted Pt/TiO 2 Catalyst. Appl. Catal. B 2016, 188, 189-197. [CrossRef]

15. Yu, L.; Shao, Y.; Li, D. Direct Combination of Hydrogen Evolution from Water and Methane Conversion in a Photocatalytic System over Pt/TiO 2. Appl. Catal. B 2017, 204, 216-223. [CrossRef]

16. Wu, X.; Liu, S.; Weng, D. Effects of Tungsten Oxide on Soot Oxidation Activity and Sulfur Poisoning Resistance of $\mathrm{Pt} / \mathrm{Al}_{2} \mathrm{O}_{3}$ Catalyst. Catal. Sci. Technol. 2011, 1, 644-651. [CrossRef]

17. Kim, S.S.; Park, K.H.; Hong, S.C. Correlation Research between Simultaneous Removal Reaction for NOx, Soot and Physico-Chemical Properties of $\mathrm{Pt}_{/} \mathrm{TiO}_{2}$ 's Supports. Appl. Chem. Eng. 2010, 21, 178-182.

18. Ruppert, A.M.; Paryjczak, T. Pt/ZrO $/ \mathrm{Zr}_{2} / \mathrm{TiO}_{2}$ Catalysts for Selective Hydrogenation of Crotonaldehyde: Tuning the SMSI Effect for Optimum Performance. Appl. Catal. A 2007, 320, 80-90. [CrossRef]

19. Ladera, R.; Finocchio, E.; Rojas, S.; Busca, G.; Fierro, J.L.G.; Ojeda, M. Supported WOx-Based Catalysts for Methanol Dehydration to Dimethyl Ether. Fuel 2013, 113, 1-9. [CrossRef]

20. Hemmann, F.; Jaeger, C.; Kemnitz, E. Comparison of Acidic Site Quantification Methods for a Series of Nanoscopic Aluminum Hydroxide Fluorides. RSC Adv. 2014, 4, 56900-56909. [CrossRef]

21. Seo, M.; Lee, D.-W.; Lee, K.-Y.; Moon, D.J. Pt/Al-SBA-15 Catalysts for Hydrocracking of $C_{21}-C_{34}$ n-Paraffin Mixture into Gasoline and Diesel Fractions. Fuel 2015, 143, 63-71. [CrossRef]

22. Seo, M.; Kim, S.; Lee, D.-W.; Jeong, H.E.; Lee, K.-Y. Core-Shell Structured, Nano-Pd-Embedded $\mathrm{SiO}_{2}-\mathrm{Al}_{2} \mathrm{O}_{3}$ Catalyst $\left(\mathrm{Pd} @ S i O_{2}-\mathrm{Al}_{2} \mathrm{O}_{3}\right)$ for Direct Hydrogen Peroxide Synthesis from Hydrogen and Oxygen. Appl. Catal. A 2016, 511, 87-94. [CrossRef]

23. Kanungo, S.; Keshri, K.S.; van Hoof, A.J.F.; d'Angelo, M.F.N.; Schouten, J.C.; Nijhuis, T.A.; Hensen, E.J.M.; Chowdhury, B. Silylation Enhances the Performance of $\mathrm{Au} / \mathrm{Ti}-\mathrm{SiO}_{2}$ Catalysts in Direct Epoxidation of Propene Using $\mathrm{H}_{2}$ and $\mathrm{O}_{2}$. J. Catal. 2016, 344, 434-444. [CrossRef]

Publisher's Note: MDPI stays neutral with regard to jurisdictional claims in published maps and institutional affiliations.

(C) 2020 by the authors. Licensee MDPI, Basel, Switzerland. This article is an open access article distributed under the terms and conditions of the Creative Commons Attribution (CC BY) license (http://creativecommons.org/licenses/by/4.0/). 